\title{
A slack-based measure of agricultural efficiency in the European Union countries
}

\author{
Kristina Kocisova \\ Faculty of Economics, Technical University of Kosice, Slovakia \\ Slovakia \\ Kristina.Kocisova@tuke.sk
}

\section{Beata Gavurova}

Faculty of Economics, Technical University of Kosice,

Slovakia

Beata.Gavurova@tuke.sk

\section{Anna Kotaskova}

Faculty of Economics and Business, Paneuropean University in

Bratislava

Slovakia

Anna.Kotaskova@gmail.com

Abstract. The main aim of this study is to examine the relative efficiency of agriculture in the European Union using Data Envelopment Analysis for the period 20052015. We have examined the relative efficiency using non-radial and non-oriented slacks-based model (SBM) under the assumption of a variable return to scale. We have looked for causes of inefficiency and have come up with the recommendations how to change input and output variable to reach the efficiency frontier. The results show that, on average, the European Union agricultural sector has been performing efficiently, and its development could be considered as stable. After taking into account the size of the economies in form of gross domestic product in market prices, we can say, that the efficiency was positively affected mainly by the development in large countries. By examining the optimal values for the variables used in the SBM model, it has been found that on average for the movement on the efficiency frontier it is necessary to reduce both inputs (labour and utilised agricultural area) and simultaneously increase both outputs (animal and crop production).

Keywords: Data Envelopment Analysis, SBM model, non-radial, non-oriented, agriculture, European Union countries.

JEL Classification: C14, Q10 


\section{INTRODUCTION}

Agriculture plays an essential role for the humankind, because human welfare depends on the volume and stability of agricultural production, as provided by crop yield and cultivated area (Garibaldi et al., 2011; Rasciauskaite, \& Volkov, 2011). Agriculture is one of the economic sectors that is under the permanent attention of policy-makers. The European Union agriculture is constantly undergoing structural changes that significantly affect its efficiency and productivity growth not only in agriculture itself but also in the economy as a whole (Azizi \& Ramezanzadeh, 2016; Pawliczek et al., 2015; Nagyová et al., 2016; Remeikiene \& Gaspareniene, 2017; Tamuliene, Raupeliene \& Kazlauskiene, 2017; Termosa, 2017).

In today's highly competitive landscape efficiency is one of the most debated topics that helps identifying strengths and weaknesses of the evaluated units, including those related to the agricultural sector (Lorant \& Farkas, 2015; Strýčková, 2017; Venclová et al., 2013; Zalizko, Fedun \& Martynenkov, 2017). This paper tries to examine the efficiency in terms of effective relationship between consumed inputs and produced outputs. The reason for this analysis is that policymakers and industry's participants are interested in assessing the economic outlook of agriculture production with the aim of not only assessing the measure of profitability and financial health but also to measure the production efficiency. For this purpose, the Data Envelopment Analysis (DEA) is used to estimate technical efficiency of agricultural sectors in the European Union countries. We have examined the production efficiency of the two main agricultural products - crop and animal outputs, using two main sources: labour and land.

The novelty of this paper lies in application of non-radial and non-oriented slacks-based model in evaluating the efficiency of the agricultural sectors in the EU countries during the period 2005-2015. The advantage of a non-oriented model is that it captures the desire to improve both inputs and outputs simultaneously. The non-radial aspect captures the movements on the efficiency frontier that will be not only proportional but for the movement on the efficiency frontier, necessary will be also a non-radial movement expressed via the values of slacks.

The DEA method has become very popular in many areas while assessing the efficiency, due to its ability to work with multiple inputs and multiple outputs in the course of efficiency evaluation. In this study the concept of efficiency will be defined, the average relative efficiency in EU agriculture sector during the years 2005-2015 will be analysed, and the recommendations on how to increase the efficiency will be carried out. The aim is to point out how the efficiency of the agricultural sector in Europe can increase, and this way will be able to meet the needs of the domestic market and to occupy a leading position on the world market for agricultural products and foodstuffs securing its multiculturalism.

Fulfilling the aim of this paper may bring benefits to the three main groups. Understanding the level of efficiency is important to managers of agricultural firms since it reflects the quality of daily operations using inputs and producing outputs, and further their decisions could be based on this newly obtained knowledge. The other group which can benefit from such information are policymakers. They could use this information to compare the performance of agriculture before and after any regulatory change has taken place, and therefore they can evaluate whether these changes have been beneficial or not (Gavurova et al., 2016; Máté et al., 2017). Finally, researchers can also benefit from evaluation of agricultural efficiency (Dirner and Pavelek, 2016). They can use previous studies to study gradual evolution in methods applied for efficiency measurement, which may help them identify the gap in the research field (Kočišová, 2015; Reiff et al., 2016).

This study is divided into the following sections. Section 1 is the review of literature dealing with assessing the efficiency in agriculture. Next, section 2 explains the methods used for efficiency measurement and describes the selection of variables. Section 3 contains analysis of the collected data and also presents the authors' own findings. The last section concludes the paper with a summary of key findings. 


\section{LITERATURE REVIEW}

In modern society there exist many approaches how to define the efficiency. In this paper we used definition presented by Farrell (1957), who suggested that an efficiency has two components: the technical and allocative efficiency. These two components could be combined into an overall economic efficiency that could be studied in terms of an input-oriented or an output-oriented model. Farrell's study led to the development of a number of methods for input and output efficiency measurement. Between them, the most important were the Stochastic Frontier Approach (SFA), and Data Envelopment Analysis (DEA). The difference between mentioned methods is that DEA belongs to non-parametric methods (Staníčková, 2017; Cyrek, 2017), while the SFA is a parametric method.

Table 1

Review of the literature

\begin{tabular}{|c|c|c|c|}
\hline $\begin{array}{c}\text { Author, } \\
\text { (Year) }\end{array}$ & $\begin{array}{c}\text { Research } \\
\text { area }\end{array}$ & Input/output variables & Main findings \\
\hline $\begin{array}{l}\text { Mathijs and } \\
\text { Vranken, } \\
(2000)\end{array}$ & $\begin{array}{l}\text { Bulgaria, } \\
\text { Hungary }\end{array}$ & $\begin{array}{l}\text { Inputs: total cultivated area; } \\
\text { annual working units; } \\
\text { capital } \\
\text { Outputs: value of physical } \\
\text { production }\end{array}$ & $\begin{array}{l}\text { Most of farms reached an efficiency } 30-60 \% \text {. They } \\
\text { found out that the cooperatives }(44 \%) \text { were on } \\
\text { average less efficient than companies }(50 \%) \text {, while } \\
\text { companies performed worse than family farms } \\
(58 \%) \text {. }\end{array}$ \\
\hline $\begin{array}{l}\text { Khai and } \\
\text { Yabe, (2011) }\end{array}$ & Vietnam & $\begin{array}{l}\text { Inputs: seed expenditures, } \\
\text { pesticide costs, fertilizer } \\
\text { quantity, machinery } \\
\text { services, hired labour, small } \\
\text { tools and energy, other rice } \\
\text { expenditures, family labour } \\
\text { for rice, rice land area } \\
\text { Outputs: rice output }\end{array}$ & $\begin{array}{l}\text { They calculated technical efficiency of rice farmers } \\
\text { around } 81.6 \% \text {. As the most important factors with a } \\
\text { positive impact on efficiency were pointed intensive } \\
\text { labour in rice cultivation, irrigation, and education. }\end{array}$ \\
\hline $\begin{array}{l}\text { Akande, } \\
\text { (2012) }\end{array}$ & EU-15 & $\begin{array}{l}\text { Inputs: labour, utilized } \\
\text { agricultural area, buildings, } \\
\text { machinery, cost of } \\
\text { materials, livestock } \\
\text { Outputs: crop output, } \\
\text { animal output }\end{array}$ & $\begin{array}{l}\text { For the whole EU-15 region was observed average } \\
\text { efficiency of } 87 \% \text {. By breaking the EU-15 into four } \\
\text { regional groups, the Western European region was } \\
\text { the most efficient }(95 \%) \text {, while the Central } \\
\text { European region and the Southern European region } \\
\text { reached the same level of average efficiency }(85 \%) \text {. } \\
\text { As the least efficient was marked Northern } \\
\text { European region }(84 \%) \text {. }\end{array}$ \\
\hline $\begin{array}{l}\text { Hengzhou } \\
\text { and Tong, } \\
(2013)\end{array}$ & China & $\begin{array}{l}\text { Inputs: area of farmland } \\
\text { measured in hectares, total } \\
\text { power of agricultural } \\
\text { machinery measured in } \\
\text { kilowatts, number of } \\
\text { workers } \\
\text { Outputs: agricultural } \\
\text { income of households } \\
\text { measured in RMB Yuan }\end{array}$ & $\begin{array}{l}\text { The average value of efficiency of the farmland used } \\
\text { for all investigated households was } 75.8 \% \text {, in other } \\
\text { words, the space for efficiency improvement was } \\
24.2 \% \text {. }\end{array}$ \\
\hline $\begin{array}{l}\text { Zamania, } \\
\text { Shahabinejad, } \\
\text { Yaghoubi, } \\
\text { (2013) }\end{array}$ & $\begin{array}{l}\text { MENA } \\
\text { countries }\end{array}$ & $\begin{array}{l}\text { Inputs: land, tractor, } \\
\text { labour, livestock, fertilizer } \\
\text { Outputs: feed, seed }\end{array}$ & $\begin{array}{l}\text { They investigated the levels of technical efficiency in } \\
\text { the agricultural sector of MENA countries applying } \\
\text { DEA and SFA approaches during the period 2007- } \\
\text { 2008. The highest average efficiency was reached } \\
\text { under the BCC model, then under the CCR model } \\
\text { and the lowest efficiency was reached under the } \\
\text { SFA model. As the most efficient was marked the } \\
\text { Qatar. They found out that both methods (DEA } \\
\text { and SFA) provided the same rank for countries. }\end{array}$ \\
\hline
\end{tabular}

Source: Prepared by authors 
The objective of this study is to examine the relative technical efficiency of the agriculture in the EU countries using DEA. Therefore, Table 1 shows a summary of the studies dealing with the application of DEA in the agricultural sector worldwide. In each study the different input and output variables were used to study, the efficiency of agriculture in the selected country.

After examination the papers dealing with the application of DEA to measure efficiency in Slovakia and the Czech Republic we have concluded that there is a lack of such research papers in the agricultural sector. The scale efficiency was investigated in the study of Bielik and Rajč́ková (2004). They investigated the connection between farm size and efficient land use on a sample of 110 agricultural enterprises of varying sizes in the Slovak Republic through DEA (Bobáková, 2017). They found out that about 10\% of analysed farms operated at the optimal scale, $77 \%$ at the above optimal scale and $13 \%$ could increase their efficiency by increasing their agricultural land area.

Bielik et al. (2010) analysed the return to scale in Slovakia for a period 1999-2007. They estimated that the most of the companies operated under the conditions of decreasing returns to scale. They concluded that the total input exploitation in agricultural companies was not profitable because, in comparison with inputs, lower profits were recorded. On the basis of these results, it was not possible to estimate which inputs were indispensable for optimal performance, despite the fact that there the low input profitability was confirmed comp. (Michalski, 2017; Bem \& Michalski, 2015; Szczygieł et. al. 2015; Hornungová, 2017).

The efficiency was also investigated in the study of Čechura (2010), who found out that the technical inefficiency was a significant phenomenon in Czech agricultural sector. The average efficiency was around $90 \%$ for Czech agricultural companies.

\section{METHODOLOGY AND DATA DESCRIPTION}

This paper try to examine efficiency by looking at the relationship between inputs used and outputs produced. Data Envelopment Analysis (DEA) is one of the available methods, which is able to deal with multiple inputs and multiple outputs in efficiency evaluation.

The basic DEA model developed by Charnes et al. (1978) was based on the assumption of a constant return to scale. This basic model was modified by Banker et al. (1984) to be based on a variable return to scale assumption. Both these DEA models were constructed in input and output-oriented form.

In this paper, the evaluated units (DMU) are agricultural sectors. Consider $n$ agricultural sectors $\left(D M U_{j}\right.$, $j=1,2, \ldots, n)$, each consuming $m$ different inputs $\left(x_{i j}, i=1,2, \ldots, m\right)$ to produce $s$ different outputs $\left(y_{r j}, r=1,2, \ldots, s\right)$. The matrix of inputs is marked as follows $X=\left\{x_{i j}, i=1,2, \ldots, m ; j=1,2, \ldots, n\right\}$ and the matrix of outputs $Y=$ $\left\{y_{r j}, r=1,2, \ldots, s ; j=1,2, \ldots, n\right\}$. We used the assumption of a variable to scale (as agricultural firms, as well as whole agricultural sectors in the real world usually don't operate under their optimal size) combined with a non-radial and non-oriented SBM model in evaluating agricultural sectors in the European Union countries during the period since 2005 to 2015. The non-oriented aspect of the model captures the desire to improve both the inputs and outputs simultaneously.

Tone (2001) proposes a slack-based measure of efficiency (SBM model), based on the assumption, that data set is positive, i.e. $X>0$ and $Y>0$, and there exist the non-negative slacks $s_{r}^{+}, s_{i}$. The slacks $s^{+}$, and $s$ indicate the input excess and output shortfall of this expression. In an effort to estimate the efficiency of $D U_{q}\left(x_{i q}, y_{r q}\right)$, Tone (2001) formulated the following minimisation program:

Minimise

$$
p=\frac{1-\frac{1}{m} \sum_{i=1}^{m}\left(s_{i}^{-} / x_{i q}\right)}{1+\frac{1}{s} \sum_{r=1}^{s}\left(s_{r}^{+} / y_{r q}\right)}
$$


Subject to

$$
\begin{aligned}
& x_{i q}=\sum_{j=1}^{n} x_{i j} \lambda_{j}+s_{i}^{-} \quad i=1,2, \ldots, m \\
& y_{r q}=\sum_{j=1}^{n} y_{r j} \lambda_{j}-s_{r}^{+} \quad r=1,2, \ldots, s \\
& \lambda_{j, s_{r}^{+}, s_{i}} \geq 0 \\
& \sum_{j=1}^{n} \lambda_{j}=1
\end{aligned}
$$

Where $y_{r q}$ are the produced amounts of $r^{\text {th }}$ output $(r=1,2, \ldots, s)$ for $D M U_{q}, x_{i q}$ are the consumed amounts of $i^{\text {th }}$ input $(i=1,2, \ldots, m)$ for $D M U_{q}, y_{r j}$ are the produced amounts of $r^{\text {th }}$ output for $D M U_{j}(j=1,2, \ldots, n), x_{i j}$ are the consumed amounts of $i^{\text {th }}$ input for $D M U_{j}(j=1,2, \ldots, n), s_{i}^{-}$and $s_{r}^{+}$are the input or output slacks, $\lambda_{j}$ is the weight assigned to the $D M U_{j}$.

An agricultural sector is fully SBM-efficient if $p^{*}=1$ and all slack variables are equal to zero, i.e. there is no input excess and no output shortfalls in any optimal solution. If the slack variables aren't equal to zero and $p^{*}<1$, it is necessary to make non-radial shift expressed by slack variables to achieve efficiency. For each inefficient agricultural sector, we can make SBM-projection on efficiency frontier, by deleting the input excess and augmenting the output shortfalls.

The described methodology of non-radial and non-oriented SBM model is used to measure the average efficiency of European Union agricultural sector, in general. We are aware of the fact, the averaging without any respect to the size of economy (or agricultural sector), causes loss of information, and therefore we implemented into analysis a sized-adjusted average efficiency, which can be used for analysing the issue of optimal economy size by comparing with "simple" average efficiency score. According to Stavárek (2004), the size-adjusted average efficiency $(A M)$ was calculated as:

$$
A M=\sum_{j=1}^{n} w_{j} \cdot p_{j}
$$

Where $A M$ is the size-adjusted average efficiency; $w_{j}$ are the weights calculated as a share of $D M U_{j}$ $(j=1,2, \ldots, n)$ gross domestic product (GDP) on total GDP of all estimated DMUs, where GDP is expressed at market prices at EUR million; $p_{j}$ is the observed efficiency for the $D M U_{j}$ using non-radial and nonoriented SBM model.

The data set applied to this paper have been obtained from the database published by the Eurostat on an annual basis. Based on the literature studied, there was set up the set of the following input and output variables, which could influence on the level of efficiency in each agricultural sector. In our analysis, two input variables and two output variables have been used. As the input variables were used two main production factors, work, and land. On the output side, there were considered two main products in the agricultural sector, crop production and animal production. The first input measured by the "Total labour input" and is expressed in annual work units (annual work units (AWU) = full-time employee equivalent; 1 AWU $=1800$ hours). As the second input variable was used land, measured by the "Total utilised agricultural area" expressed in hectares ( $\mathrm{Ha}$ ). This variable describes the area used for farming. It includes the arable land; permanent grassland; permanent crops; and other agricultural lands such as kitchen gardens. The variable does not include unused agricultural land, woodland and land occupied by buildings, farmyards, tracks, ponds, etc. On the output side, the first output was measured by the "Total crop output", expressed in million EUR at basic prices. The basic price is defined as the price received by the producer, after 
deduction of all taxes on products but including all subsidies on products. The concept of output comprises sales, changes in stocks, and crop products used as animal feeding stuffs, for processing and own final use by the producers. The second output variable was measured by the "Total animal output", expressed in million EUR at basic prices. The basic price is defined as the price received by the producer, after deduction of all taxes on products but including all subsidies on products. The concept of output comprises sales, changes in stocks, and products used for processing and own final use by the producers (Michalski, 2014, 2016a).

\section{EMPIRICAL ANALYSIS AND RESULTS}

Based on the described methodology we would like to investigate the relative efficiency of the agriculture in the EU during the period 2005-2015, and to suggest recommendations increase the efficiency in average. The term "relative" efficiency refers to the efficiency of agricultural sectors within the group of evaluated countries and under the given criteria (input and output variables).

We investigated efficiency using non-radial and non-oriented slacks-based measure (SBM) of efficiency under the assumption of a variable return to scale, under a defined set of input and output variables. The descriptive statistics of average input and output values during the whole analysed period are presented in next table (Table 2).

Table 2

Descriptive statistics on input and output variables; 2005-2015

\begin{tabular}{|c|c|c|c|c|}
\hline & $\begin{array}{l}\text { Total labour input } \\
\text { (1000 AWU) }\end{array}$ & $\begin{array}{c}\text { Total utilised } \\
\text { agricultural area } \\
\qquad(1000 \mathrm{Ha})\end{array}$ & $\begin{array}{l}\text { Total crop output } \\
\text { (mil. EUR) }\end{array}$ & $\begin{array}{l}\text { Total animal } \\
\text { output } \\
\text { (mil. EUR) }\end{array}$ \\
\hline Average & 388.33 & 6476.48 & 7098.07 & 5464.64 \\
\hline Min & 3.53 & 10.25 & 43.58 & 67.28 \\
\hline Max & 2596.00 & 32345.80 & 44407.20 & 27102.30 \\
\hline St. dev. & 537.70 & 7683.92 & 9926.04 & 6827.69 \\
\hline
\end{tabular}

Source: Authors' calculations

The development of average input and output values in each year of analysed period are presented in next figure (Figure 1). As can be seen in Figure 1, during the analysed period the average labour input in whole European Union agricultural sector decreased. At the beginning of analysed period, in 2005, the "Total labour input" had value 456.30 thousand of annual work units. On the other hand, at the end of analysed period, in 2015, the value of "Total labour input" was only 340.45 thousand of annual work units. The value of this input corresponds to the work performed by one person who is occupied on agricultural sector on a full-time basis. According to this, we can say, that hours performed by one person decreased. This could be connected with the new technologies used in the agricultural sector which gradually replace the working person in the sector. In the case of second input, "Total utilised agricultural area", the average value also decreased, from 6673.81 thousand of $\mathrm{Ha}$ in 2005 to 6384.97 thousand of $\mathrm{Ha}$ in 2015. On the output side, there can be seen the increase, where crop and animal production increased by $25 \%$, respectively $20 \%$. 

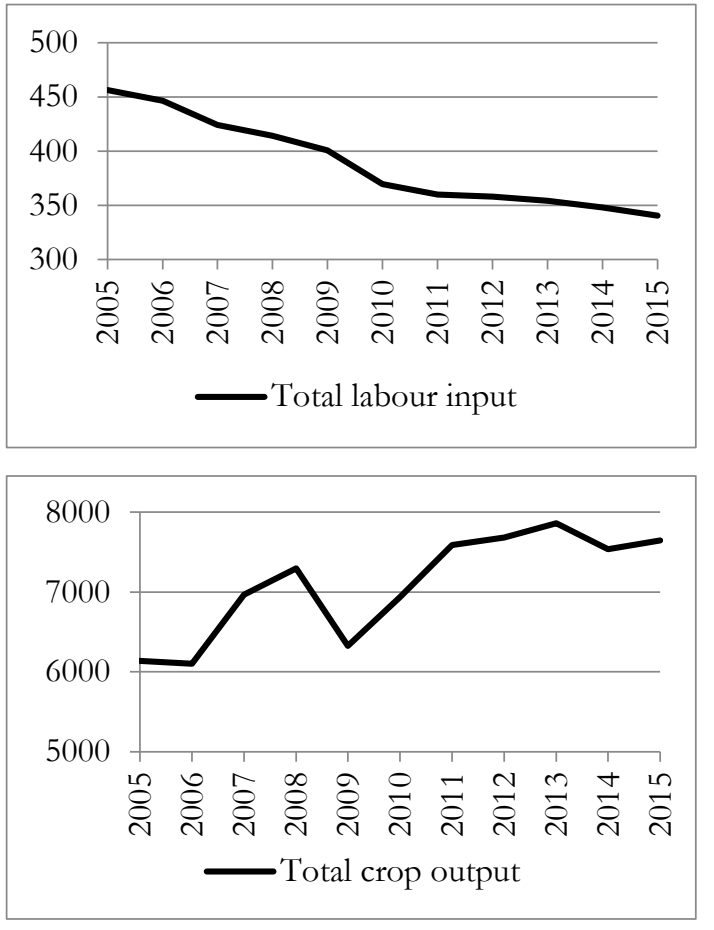
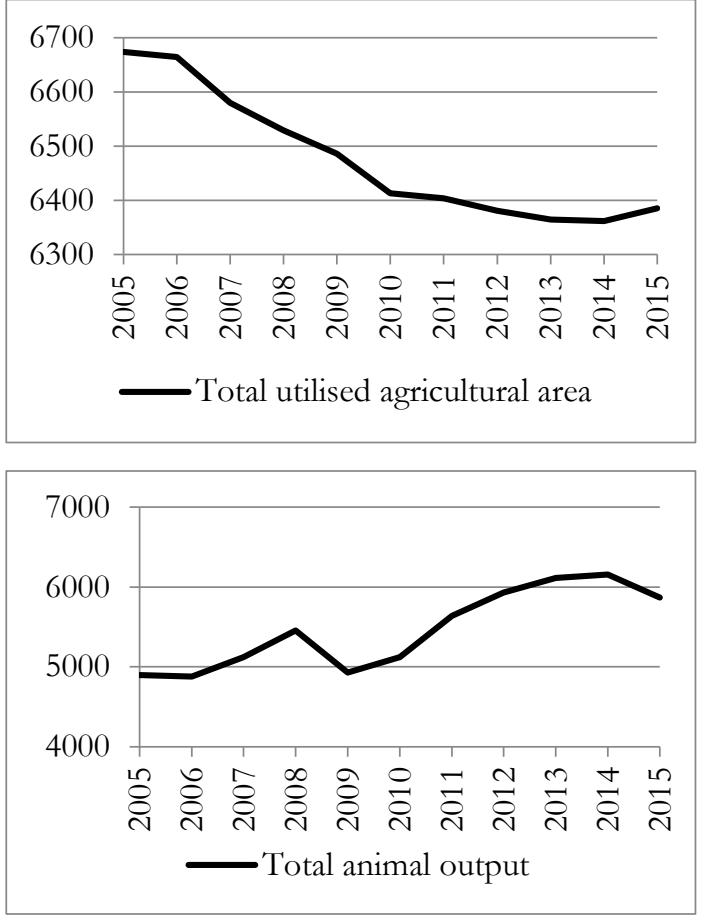

Figure 1. Development of average input and output variables Source: Author's calculations

The efficiencies in this paper were estimated using the computer program "DEA Solver-Pro software". The descriptive statistic of the relative efficiency calculated through the non-radial and non-oriented SBM model for all of the periods under consideration (since 2005 to 2015) is displayed in Table 3.

We pooled the cross-country data and used it to define a common best practice efficiency frontier for each year. Table 3 shows the results for average efficiencies obtained relative to the whole sample during the analysed period. According to results, we can say that the average efficiency of the EU agriculture was relatively stable over time. The average non-oriented and non-radial SBM efficiency at the beginning of the analysed period was $40.07 \%$, indicating that agricultural sector had to improve their efficiency on average by $59.93 \%$. This efficiency slightly rose to $43.55 \%$ in 2015 , indicating decreasing room for efficiency improvement (56.45\%). Almost during the whole analysed period, 7 agricultural sectors were marked as efficient, which means that $25 \%$ of all analysed sample can effectively use their inputs to produce outputs under the analysis. The highest variability can be seen in last year (2015) when the standard deviation of efficiency scores reached the highest value. On the other hand, the lowest volatility was observed in 2008. The greatest difference between the minimum and maximum was recorded in 2005 when the minimum was 0.0394 and the maximum score was 1 . As can be seen in the table, most agricultural sectors operated under the condition of constant return to scale, but their number during the analysed period decreased while the number of DMUs operated under the increasing return (under the given inputs could be achieved higher outputs) to scale increased. Within the group of agricultural sectors operating under the condition of increasing return to scale were smaller countries like Belgium, Czech Republic, Luxembourg, and Slovakia. The number of DMUs operated under the condition of decreasing return to scale (which means, that at a given inputs the level of outputs was too high) was relative stable. Within this group could be seen the biggest countries like Germany, Spain, France, Italy, United Kingdom and Poland. 
Table 3

Descriptive statistics of SBM efficiency; 2005-2015

\begin{tabular}{|c|c|c|c|c|c|c|c|c|c|c|c|}
\hline & 2005 & 2006 & 2007 & 2008 & 2009 & 2010 & 2011 & 2012 & 2013 & 2014 & 2015 \\
\hline $\begin{array}{l}\text { Number of } \\
\text { DMUs }\end{array}$ & 28 & 28 & 28 & 28 & 28 & 28 & 28 & 28 & 28 & 28 & 28 \\
\hline $\begin{array}{l}\text { Number } \\
\text { (and \%) } \\
\text { of efficient } \\
\text { DMUs }\end{array}$ & $\begin{array}{r}7 \\
(25 \%)\end{array}$ & $\begin{array}{r}7 \\
(25 \%)\end{array}$ & $\begin{array}{r}7 \\
(25 \%)\end{array}$ & $\begin{array}{r}7 \\
(25 \%)\end{array}$ & $\begin{array}{r}7 \\
(25 \%)\end{array}$ & $\begin{array}{r}7 \\
(25 \%)\end{array}$ & $\begin{array}{r}7 \\
(25 \%)\end{array}$ & $\begin{array}{r}7 \\
(25 \%)\end{array}$ & $\begin{array}{r}7 \\
(2 \%)\end{array}$ & $\begin{array}{r}7 \\
(25 \%)\end{array}$ & $\begin{array}{r}8 \\
(29 \%)\end{array}$ \\
\hline Maximum & 1 & 1 & 1 & 1 & 1 & 1 & 1 & 1 & 1 & 1 & 1 \\
\hline Minimum & 0.0394 & 0.0423 & 0.0457 & 0.0565 & 0.0532 & 0.0509 & 0.0586 & 0.0557 & 0.0562 & 0.0597 & 0.0605 \\
\hline $\begin{array}{l}\text { Average } \\
\text { efficiency }\end{array}$ & 0.4007 & 0.3927 & 0.4045 & 0.4046 & 0.4042 & 0.4054 & 0.4140 & 0.4138 & 0.4077 & 0.4123 & 0.4355 \\
\hline $\begin{array}{l}\text { Size- } \\
\text { adjusted eff. } \\
\text { (AM) }\end{array}$ & 0.7268 & 0.7081 & 0.7094 & 0.7061 & 0.7182 & 0.7142 & 0.7174 & 0.7228 & 0.7174 & 0.7292 & 0.8092 \\
\hline $\begin{array}{l}\text { Standard } \\
\text { deviation }\end{array}$ & 0.3829 & 0.3857 & 0.3819 & 0.3762 & 0.3806 & 0.3812 & 0.3781 & 0.3814 & 0.3801 & 0.3789 & 0.3962 \\
\hline \multicolumn{12}{|c|}{ Return to scale - number of DMUs } \\
\hline $\begin{array}{l}\text { Constant } \\
\text { return to } \\
\text { scale }\end{array}$ & 21 & 21 & 21 & 20 & 21 & 19 & 18 & 19 & 17 & 15 & 16 \\
\hline $\begin{array}{l}\text { Increasing } \\
\text { return to } \\
\text { scale }\end{array}$ & 2 & 2 & 2 & 2 & 2 & 4 & 4 & 4 & 6 & 7 & 6 \\
\hline $\begin{array}{l}\text { Decreasing } \\
\text { return to } \\
\text { scale }\end{array}$ & 5 & 5 & 5 & 6 & 5 & 5 & 6 & 5 & 5 & 6 & 6 \\
\hline
\end{tabular}

Source: Authors' calculations

As was mentioned, the averaging without any respect to the country's size can cause the loss of information. Therefore, we included into analysis a sized-adjusted average efficiency, which can be used for analysing the issue of optimal size by comparing with "simple" average efficiency score. The efficiencies in individual countries were weighted by the share of their GDP at market prices to total GDP in the whole sample. According to size-adjusted values, we can see that the level of efficiency was higher, but the development could also be considered as stable. The reason of higher level of size-adjusted average efficiency could be a fact, that large countries like Germany, France, Italy, United Kingdom and Netherland, which were marked as efficient were also the countries with the highest values of GDP. So they have a significant positive impact on the total average efficiency score. On the other hand, countries with the lowest efficiencies were also countries with the lower values of GDP (e.g. Bulgaria, Croatia, Latvia, and Romania). This is in line with finding in other studies, that smaller countries dominate usually operate under the condition of constant, or decreasing return to scale, while in the model under the variable return to scale countries on the efficiency frontier are on average much larger. Hence, in a case of common efficiency 
analysis, we can generalise, those bigger countries mainly operated at a decreasing return to scale. Big countries didn't fully utilise their inputs (labour and land) and thus exceeded the crop and animal production.

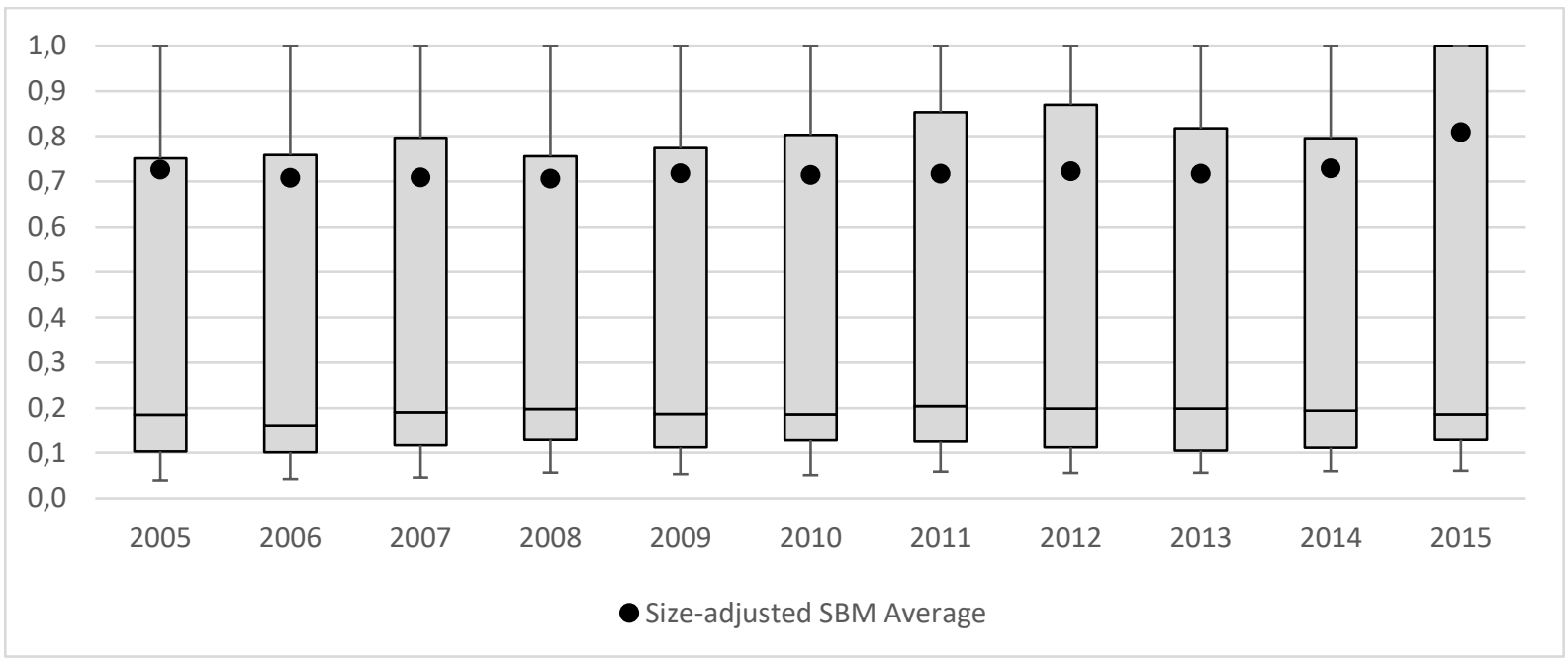

Figure 2. SBM efficiency of EU agricultural sector

Source: Author's calculations

The results of the analysis were evaluated through the boxplot. Figure 2 shows the development of "simple" average efficiency in form of boxplots and size-adjusted average efficiency of the EU agricultural sector during period 2005-2015. As can be seen, the efficiencies were skewed toward lower values (reflected by moving the median values down) during the whole analysed period. We can also see that the highest volatility was observed in 2015 and the lowest one in 2008, which also confirmed the descriptive statistics in Table 3. Also, there can be seen the fact, that the size-adjusted SBM efficiency reached higher values compared to median calculated from the non-weighted efficiencies. The improvement if size-adjusted efficiency in last year was caused by the movement of the United Kingdom on the efficiency frontier. This again confirmed the fact that the bigger agricultural sectors performed better than the smaller ones and development in these countries had a significant impact on the average efficiency of whole EU agricultural sector (Michalski, 2016b).

One of the advantages of the DEA is, that it brings recommendation how to change input and output variable to reach the efficiency frontier. As the non-radial and non-oriented SBM model was applied the recommendations are brought on both sides (input and output) simultaneously.

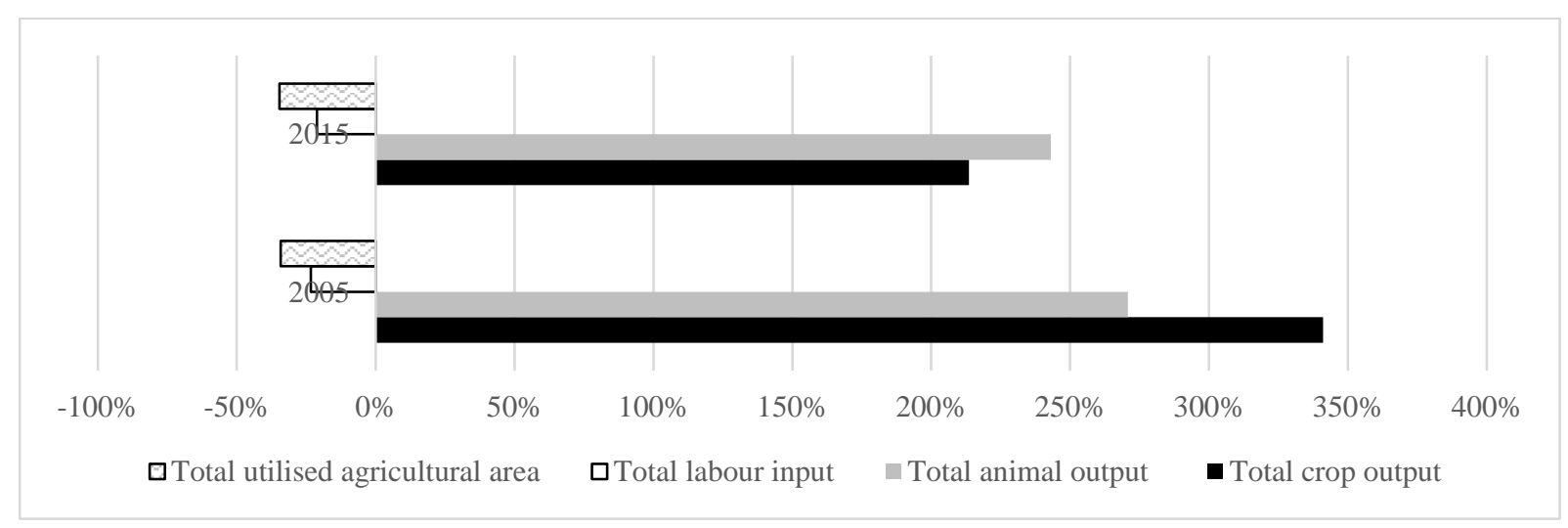

Figure 3. Potential improvement in 2005 and 2015

Source: Author's calculations 
The analysis of potential improvements was done for first and last year of analysed period. As can be seen in 2005 to reach the efficiency frontier in average was necessary to reduce both inputs, labour by $23 \%$ and utilised land by $34 \%$, and increase both outputs, crop output by $341 \%$ and animal output by $271 \%$. In 2015 to reach the efficiency frontier the reduction of inputs at the same level was necessary, but on the output side, the increase was a little bit lower.

\section{CONCLUSION}

The aim of this study was to examine the relative efficiency of the agriculture in the EU countries. We examined efficiency using non-radial and non-oriented SBM model under the assumption of a variable return to scale during the period 2005-2015. The results indicated that, in average, the agriculture in the EU countries performed efficiently, and the average efficiency was influenced mainly by the development in large countries. This was confirmed by the calculation of so-called "size-adjusted" efficiency, which takes into account the impact of the countries' size. The results also show that the number of efficient countries was relatively stable. We could also see that most of the countries operated under the condition of constant return to scale but in last years the number of agricultural sectors operated under the variable (increasing or decreasing) return to scale increased.

When we look at the main sources of inefficiency we have found out, that in general to increase efficiency it is necessary to reduce both inputs (e.g. in 2015 labour by $23 \%$ and utilised land by 34\%) and increase both outputs (e.g. in 2015 crop production by $214 \%$ and animal production by $243 \%$ ), in average.

The results of our research may be beneficial to three main groups. The knowledge of the level of efficiency is important for example for managers of agricultural firm as it reflects the quality of operations on a daily basis in using inputs and outputs and other decisions might be based on such knowledge. The second beneficent may be policymakers who should to compare the performance of agriculture before and after the adoption of regulatory actions, and thus to investigate if the actions were beneficial for the agriculture or not. The last party which can benefit from the paper could be researchers. They might use the studies which have already been undertaken to observe a gradual development in the methods for efficiency measurement, which may able them to specify the gaps in research papers as well.

We are aware of fact that our research has some limitations. Therefore, in the future, the research should be supplemented by a greater number of parameters to calculate the efficiency of the agricultural sector. Thus, it will show the real situation of the agricultural sector in Europe. In a future paper, we can also analyse each country separately, and try to analyse the impact of macroeconomic features on the efficiency of the agricultural sector in each country, which can help to form a deep, long-term and balanced strategy aimed at improving the competitiveness of agriculture and food industry and the development of rural areas.

\section{ACKNOWLEDGEMENT}

The presented work and results is part of monothematic cycle realized as part of grant titled: Cash management in small and medium enterprises that use full operating cycle. The work is supported by National Science Centre, and financed from the Polish budget resources in the years 2015-2018 according to contract UMO-2014/13/B/HS4/00192 as the research project DEC-2014/13/B/HS4/00192. The research behind this paper was supported by the Slovak Scientific Grant Agency within the project VEGA 1/0978/16. 


\section{REFERENCES}

Adamišin, P., \& Kotulič, R. (2013). Evaluation of the agrarian businesses results according to their legal form. Agricultural economics, 59(9).

Akande, O. P. (2012). An evaluation of technical efficiency and agricultural productivity growth in EU regions. Wageningen University.

Azizi, M., \& Ramezanzadeh, M. (2016). Location selection of agricultural-residuals particleboard industry through group decision: The case study of northern Iran. Economics, Management and Sustainability, 1(1), 14-22.

Banker, R. D. et al. (1984). Some Models for Estimating Technical and Scale Inefficiencies in Data Envelopment Analysis. Management Science, 9, 1078-1092.

Bednař́ková, Z., \& Jílková, J. (2012). Why is the Agricultural Lobby in the European Union Member States so Effective? Ekonomie a management, 15(2), 26-37.

Bem, A., \& Michalski G. (2015). Hospital Profitability vs. Selected Healthcare System Indicators. Central European Conference in Finance and Economics (CEFE2015), Technical University of Košice, 52-61. ISBN 9788055324678.

Bielik, P. et al. (2010). The return to scale analysis in the basic industry enterprises in the Slovak Republic. Agricultural Economics, 56(8), 359-367.

Bielik, P., \& Rajčáková, M. (2004). Scale efficiency of agricultural enterprises in Slovakia. Agricultural Economics, 50(8), 331-335.

Bobáková, V. (2017). The formation of regional self-government in the Slovak Republic and its sources of funding. Administratie si Management Public, (28), 97-115.

Čechura, L. (2010). Estimation of technical efficiency in Czech agriculture with respect to firm heterogenity. Agricultural Economics, 56(4), 183-191.

Cyrek, M. (2017). Social efficiency of employment in three sectors - a compari-son of Polish regions. Equilibrium. Quarterly Journal of Economics and Economic Policy, 12(3), 417-432. doi: https:/ / doi.org/10.24136/eq.v12i3.22.

Dirner, V., \& Pavelek, Z. (2016). Aspects of classification of energy sources in terms of their position in the sector of the economy. Acta Montanistica Slovaca, 21(4), 287-297.

Charnes, A. et al. (1978). Measuring the Efficiency of Decision-making Units. European Journal of Operational Research, 6, 429-444.

Farrell, M. J. (1957). The Measurement of Productive Efficiency. Journal of the Royal Statistical Society, 3, $253-290$.

Garibaldi, L.A, et al. (2011). Global growth and stability of agricultural yield decrease with pollinator dependence. Proceedings of the National Academy of Sciences, 14, 5909-5914.

Gavurova, B., Perzelova, I., \& Bencoova, B. (2016). Economic aspects of renewable energy use - application of support schemes based on a particular biogas plant in Slovakia. Acta Montanistica Slovaca, 21(3), 217-228.

Hengzhou, X., \& Tong, Ch. (2013). Impact of farmers' differentiation on farmland-use efficiency: Evidence from household survey data in rural China. Agricultural Economics, 59(5), 227-234.

Hornungová, J. (2017). Nonfinancial performance evaluation as significant area of strategic business management, Business: Theory and Practice, 18: 71-78 (03 May 2017). doi: https://doi.org/10.3846/btp.2017.008

Khai, H.V., \& Yabe, M. (2011). Technical efficiency analysis of rice production in Vietnam. Journal of ISS AAS, 1, 135146.

Kočišová, K. (2015). Application of the DEA on the measurement of efficiency in the EU countries. Agricultural Economics, 61(2), 51-62.

Lorant, A., \& Farkas, M.F. (2015). Risk management in the agricultural sector with special attention to insurance. Polish Journal of Management Studies, 11(2), 71-82.

Malá, Z. (2011). Efficiency Analysis of Czech Organic Agriculture. Ekonomie a management, 14(1), 14-28.

Máté, D., Oláh, J., Laknern, Z., \& Popp, J. (2017). Food chemistry patents influence on productivity: A case study of a sectoral approach in various OECD countries. Polish Journal of Management Studies, 16(2), 160-170. doi:10.17512/pjms.2017.16.2.14

Mathijs, E., \& Vranken, L. (2000). Farm restructuring and efficiency in transitions: Evidence from Bulgaria and Hungary. American Agricultural Economics Association Annual Meeting, Tampa. 1-26.

Michalski, G. (2014). V alue-Based Working Capital Management, Palgrave Macmillan, ISBN 978-1-137-39799-7. 
Michalski, G (2016a). Full operating cycle influence on the food and beverages processing firms characteristics, Agricultural Economics, 62(2), 71-77.

Michalski, G. (2016b). Risk Pressure and Inventories Levels. Influence of Risk Sensitivity on Working Capital Levels, Economic Computation and Economic Cybernetics Studies and Research, 50(1), 189-196.

Michalski, G. (2017). Nonprofit Organizations [Synonyms, Definitions], Global Encyclopedia of Public Administration, Public Policy, and Governance. Springer International Publishing, 1-5.

Nagyová, L. et al. (2016). Food security drivers: economic sustainability of primary agricultural production in the Slovak Republic, Journal of Security and Sustainability Issues, 6(2), 259-274.

Pawliczek, A., Kozel, R., Vilamová, Š., \& Janovská, K. (2015). On the strategic planning, innovation activities and economic performance of industrial companies. Acta Montanistica Slovaca, 20(1), 16-25.

Rasciauskaite, D., \& Volkov, A. (2011). Challenges of Common Agricultural Policy Development. Business: Theory and Practice, 12, 120-130 (22 Jun 2011). doi: https://doi.org/10.3846/btp.2011.13

Remeikiene, R., \& Gaspareniene, L. (2017). Green farming development opportunities: the case of Lithuania. Oeconomia Copernicana, 8(3), 401-416. doi: https://doi.org/10.24136/oc.v8i3.25.

Staníčková, M. (2017). Can the implementation of the Europe 2020 Strategy goals be efficient? The challenge for achieving social equality in the European Union. Equilibrium. Quarterly Journal of Economics and Economic Policy, 12(3), 383-398. doi: https://doi.org/10.24136/eq.v12i3.20.

Reiff, M., Surmanová, K., Balcerzak, A. P., \& Pietrzak, M. B. (2016). Multiple Criteria Analysis of European Union Agriculture, Journal of International Studies, 9(3), 6274.

Stavárek, D. (2004). Banking efficiency in Visegrad countries before joining the EU. European Review of Economics and Finance, 3, 129-167.

Szczygieł, N., Rutkowska-Podolska, M., \& Michalski, G. (2015). Information and Communication Technologies in Healthcare: Still Innovation or Reality? Innovative and Entrepreneurial Value - creating Approach in Healthcare Management, in: 5th Central European Conference in Regional Science Conference Proceedings/Nijkamp Pater (eds.). Technical University of Košice, p. 1020-1029.

Strýčková, L. (2017). The Relationship Between Company Returns and Leverage Depending on the Business Sector: Empirical Evidence from the Czech Republic, Journal of Competitiveness, 9(3), 98-110. doi: https://doi.org/10.7441/joc.2017.03.07

Tamuliene, V., Raupeliene, A. \& Kazlauskiene, E. (2017). Farmers’ Preferences Selecting Agricultural Consulting Services. Montenegrin Journal of Economics, 13(4), 79-87. doi: 10.14254/1800-5845/2017.13-4.6

Termosa, I. (2017). The ways of forming the sustainable development of rural areas of Ukraine. Economics, Management and Sustainability, 2(1), 76-82.

Tone K. (2001). A Slack-Based Measure of Efficiency in Data Envelopment Analysis. European Journal of Operational Research, 130, 498-509.

Venclová, K., Šalková, A., \& Koláčková, G. (2013). Identification of Employee Performance Appraisal Methods in Agricultural Organizations, Journal of Competitiveness, 5(2), 20 - 36. doi:10.7441/joc.2013.02.02

Zalizko, V.D., Fedun, I.L. \& Martynenkov, V.I. (2017). Representative Model of Economic Development for an Agricultural Enterprise in the Context of Socioeconomic Rural Space Formation. Montenegrin Journal of Economics, 13(3), 53-62, doi: 10.14254/1800-5845/2017.13-3.5.

Zamanian, G. R., Shahabinejad, V., \& Yaghoubi, M. (2013). Application of DEA and SFA on the Measurement of Agricultural Technical Efficiency in MENA Countries. International Journal of Applied Operational Research, 2, 4351. 